\title{
Література:
}

1. Bowlby, J. A secure base: parent-child attachment and healthy human development. New York, Basic Books., 1988. $188 \mathrm{c}$.

2. Ainsworth M.D.S. Attachments beyond infacy. «American Psycologist». 1989.

3. Brzezińska, A.I. (red.) Psychologiczne portrety człowieka. Praktyczna psychologia rozwojowa. Gdańsk: GWP. 2005. 759 c.

4. Harwas-Napierała, B., Trempała, J. (red.) Psychoogia rozwoju człowieka. T.2, Charakterystyka okresów życia człowieka. Warszawa: PWN. 2000. 304 c.

DOI https://doi.org/10.30525/978-9934-588-80-8-1.18

\section{ВЗАЕМОЗВ'ЯЗОК ПСИХОДИНАМІЧНОЇ \\ ТА СИСТЕМНО-ДІЯЛЬНІСНОЇ ПАРАДИГМ У ПСИХОЛОГІЧНОМУ АНАЛІЗІ ПОЧЕРКУ}

\author{
Фармагей O. I. \\ доктор психологічних наук, старший науковий співробітник \\ Наџіональна академія Служби безпеки України \\ м. Київ, Украӥна
}

Почерк - це достатньо стійкий феномен, динамічний стереотип, визначений індивідуальними психофізіологічними особливостями людини. Науковці зазначають, що найбільш об'єктивним способом отримання достовірних даних про психіку людини $є$ аналіз продуктів іiі діяльності, зокрема почерку, який у більш вузькому розумінні становить продукт процесу письма. Дослідження психологічної науки останніх десятиліть свідчать про перспективність одночасного врахування кількох парадигм цієї галузі для вивчення одного й того ж феномену, який розширює практичну складову застосування доведених у такий спосіб теоретичних гіпотез, що й визначає актуальність наших пошуків.

Сучасна література підтверджує наявність широкого спектру джерел, у яких на підгрунті аналізу почерку робиться спроба діагностувати індивідуально-психологічні особливості особистості. Проте матеріалів, підтверджених відповідними науковими дослідженнями, обмаль. Переважна більшість наявних праць із проблем психодіагностики з використанням аналізу почерку не обгрунтовані науково. Вагомими дослідженнями 3 проблем психологічної діагностики 
почерку стали монографії Ю. Чернова (викладено новий підхід до психологічної інтерпретації ознак почерку) [1], О. Фармагея (запропоновано методику діагностики акцентуацій особистості на підставі виділення та інтерпретації ознак почерку) [2].

Мета дослідження - показати можливості та перспективи взаємозв'язку двох парадигм (психодинамічної й системно-діяльнісної) під час психологічного аналізу почерку.

Однією 3 найбільш цікавих за повнотою та обсягом достовірної інформації про особистість $є$ психодіагностична методика «чорнильні плями», яку розробив засновник терміна «психодіагностика» Г. Роршах на основі дефініцій психодинамічного підходу [3]. Сприйняття отриманих зображень таких «плям» - індивідуально зумовлений психологічний механізм. За Г. Роршахом та О. Блейлером [3, с. 21] сприйняття стає можливим у результаті того, що відчуття / група відчуттів екфорують образи спогадів, які пов'язані із комплексом відчуттів, що утворилися раніше. Свідомість згадує певні колишні відчуття, елементи яких за рахунок переживань набули особливо якісного взаємозв'язку, і чітко відрізняються від інших груп відчуттів. Таким чином, процес сприйняття містить три психічних процеси: відчуття, спогади, порівняння. Сприйняття - асоціативне прирівнювання наявних у індивіда енграм (з грецької-надпис; у психології nid енграмою розуміються сліди у пам'яті від вражень, які там збереглися) до комплексу відчуттів, що виникає в індивіда. Зіставлення психологічних i психофізіологічних особливостей відтворення на папері букв та особливості сприйняття таблиць Г. Роршаха (таблиці $\epsilon$ слабо структурованим матеріалом, створеним випадковим чином, із якого відібрані та валідизовані десять плям) дає підстави висувати гіпотезу про те, що вони мають спільні психофізіологічні механізми.

Графічне написання букв, слів, топографічне розміщення тексту $\epsilon$ створенням образів. Під час написання суб'єкт процесу письма відтворює заздалегідь сформовані проєкції тих образів, які він сприймав у процесі навчання письму. В його свідомості спочатку відбулося індивідуально зумовлене переопрацювання побаченого, а потім здійснилося репродукування на папері. Створення образів букв більш структуроване, ніж малювання та сприйняття проєктивних зображень, подібних «плямам». Водночас, певна варіативність усе ж таки зберігається. Процес письма дорослої людини $є$ автоматизованим i реалізує відповідну навичку, сформовану на підгрунті отриманих знань та умінь. Під час багаторазового відтворення образів процес письма спирається на індивідуальні психологічні особливості, які Г. Роршах пов'язує із «баченням» конкретних цілісних форм людей, тварин, ландшафтів, їх деталей, рухів тощо. 
Психофізіологічний механізм формування навичок письма за системно-діяльнісним підходом складається 3 двох етапів: 1) інтрапсихічне порівняння наявної аудіальної моделі не тільки слова, а й кожного звука із наявною енграмою букв та / або їх сполучень; 2) надання відповідної команди скелетно-м'язовій системі, зокрема, кінцівці, яка під контролем зорового аналізатора відтворює цей образ. У процесі переписування тексту до цього додається сприйняття образів літер, перекодування їх в індивідуально зрозумілі образи, їх психофонетичний аналіз, а потім зворотний процес.

Сприйняття і трактовка образу за Г. Роршахом подібні до переписування тексту, але місце створення образу букви замінюе процес вербалізації. Компаративний аналіз ідей відтворення букв на аркуші паперу в ролі образів, що описана в роботах представника глибиннопсихологічної парадигми Г. Роршаха та послідовника системнодіяльнісного підходу О. Лурія [4], говорить про те, що вони здебільшого подібні й не суперечать одна одній у межах більш високої, 3 погляду системності, загальнопсихологічної парадигми.

На основі дослідження психофізіологічних механізмів процесу письма людини і прирівнювання до особливостей механізмів «тесту сприйняття» [4] вважаємо, що в процесі аналізу форми букв (Ф у Г. Роршаха) необхідно враховувати нюанси, пов'язані із їх розміром, нахилом, наявністю елементів, передбачених прописами, та додатковими елементами. Доцільно враховувати, на скільки легко читається буква іншими, чи $\epsilon$ вона зрозумілою, чи ні ( $\Phi+$ (форма плюс) або $\Phi$ - (форма мінус) у Г. Роршаха). Одночасно, коли суб'єкт процесу письма акуратно виписує всі основні елементи букв, можна говорити про кореляцію цієї особливості із специфікою сприйняття цілісних форм (Ц) у Г. Роршаха. Відповідь на велику деталь (Д) за Г. Роршахом у почерку корелюватиметься із акцентуванням на окремих додаткових елементах у буквах, але в тому обсязі, коли це не $\epsilon$ зайвим i не пов'язано із необгрунтованим прикрашанням або погіршенням естетичного вигляду почерку [3]. Дд (дрібна деталь) у цього автора пов'язуватиметься зі зверненням уваги на зайві дрібниці в елементах почерку, хоча форма букв може читатися недостатньо якісно.

Матеріал представленої публікації дає змогу зробити такі висновки: 1) в процесі психологічного вивчення почерку вважаємо за доцільне використовувати методичний підхід, покладений в основу інтерпретації результатів діагностики за допомогою методики «чорнильні плями» Г. Роршаха; 2) особливості та деталізація викладених інтерпретаційних процедур сьогодні становить теоретичну гіпотезу та потребує проведення додаткового пілотного експерименту, спрямованого на встановлення взаємозв'язків між особливостями психологічного 
статусу того, хто пише, і створених на папері форм / груп форм букв, слів, словосполучень, рядків; 3) викладені в роботі матеріали зорієнтовані на подальший розвиток $\mathrm{i}$ дослідження описаного психодіагностичного напрямку.

\title{
Література:
}

1. Чернов Ю. Г. Психологический анализ почерка: системный подход и компьютерная реализация в психологии, криминалистике и судебной экспертизе. Москва : Генезис, 2011. 464 с.

2. Фармагей А. И. Диагностика акцентуаций личности по почерку. Методика, описание, использование. Киев: Кий. 2010. 200 с.

3. Роршах Г. Психодиагностика: Методика и результаты диагностического эксперимента по исследованию восприятия (истолкование случайных образов). Пер. с нем. Москва : «Когито-Центр», 2003. $336 \mathrm{c}$.

4. Лурия А. Р. Высшие корковые функции человека и их нарушения при локальных поражениях мезга. 2 изд. Москва : МГУ, 1969. $504 \mathrm{c}$.

DOI https://doi.org/10.30525/978-9934-588-80-8-1.19

\section{ОСОБЛИВОСТІ СТАНОВЛЕННЯ ЦІННІСНИХ ОРІЄНТАЦІЙ СТАРШИХ ДОШКІЛЬНИКІВ В УМОВАХ СІМ'ї}

\author{
Федорчук О. I. \\ науковий співробітник \\ Лабораторія психології дошкільника \\ Інститут психологї̈ імені Г. С. Костюка \\ Начіональної академії педагогічних наук України \\ м. Київ, Україна
}

Розвиток особистості це процес виникнення принципово нових психологічних якісних новоутворень, що можливе лише в результаті активної взаємодії дитини з духовно-культурним середовищем, іншими людьми та власної цілеспрямованої активної діяльності. Для дитини таким носієм та зберігачем загальнолюдських цінностей $є$ сім'я [1, c. 14].

Формувальний вплив сім'ї на дитину є багатовекторним: чинниками виступають всі складові дитячо-батьківських взаємин і характеристики сім’ї загалом. На практиці далеко не всі чинники усвідомлюються 